\title{
PENGARUH PEMBERIAN ADITIF PAKAN PROBIOTIK Rhizopus oryzae DALAM RANSUM TERHADAP BOBOT DAN PANJANG ORGAN PENCERNAAN AYAM KAMPUNG
}

(Effect of Feed Additives Probiotic Rhizopus oryzae on The Weight And Length of Digestive Organs of Kampong Chicken)

\author{
Rendika, N. ${ }^{1}$, T. Yudiarti ${ }^{2}$, dan Isroli $^{3}$ \\ ${ }^{1)}$ Mahasiswa Fakultas Peternakan Dan Pertanian Universitas Diponegoro \\ Kampus drh. Soejono Koesoemowardojo Tembalang Semarang 50275 \\ E-mail :dhenokim @gmail.com \\ ${ }^{2,3)}$ Fakultas Peternakan dan Pertanian, Universitas Diponegoro \\ Kampus drh. R. Soejono Kusumowardojo Tembalang, Semarang 50275
}

Diterima : 16 November 2015

Disetujui : 25 Juni 2016

\begin{abstract}
The purpose of this study was to investigate the effect of probiotic Rhizopus oryzae as feed additives of kampong chicken on the weight and length of digestive organs. The study was conducted on August 11 to October 11, 2014 in the poultry farm at the Faculty of Animal and Agricultural Sciences, Diponegoro University. The materials that were used in this study were 100 Day Old Chick (DOC) (unsexed) with initial body weight was $37.90 \pm 1,36$ g. Experiment al design was used Completely Randomized Design (CRD). The treatments were dose of probiotic, those were TO (control), $T 1(0,1 \%)$ and $T 2(0,2 \%)$. The results showed that the addition of probiotic Rhizopus oryzae in ration significantly affected to the majority of the weight and length of digestive organs of kampong chicken. The weight of the digestive organs of T1 was the highest followed by T2 and T0, while the length of the digestive organs of T2 was the highest followed by T1 and TO. The conclusion of the study is addition of Rhizopus oryzae with a dose of $0.1 \%$ and $0.2 \%$ in feed can improve the majority of the weight and length of the digestive organs of kampong chicken.
\end{abstract}

Keywords: Probiotic, fungi, digestive organs, kampong chicken

\begin{abstract}
ABSTRAK
Penelitian bertujuan mengetahui pengaruh pemberian probiotik Rhizopus oryzae sebagai aditif pakan pada ayam kampung terhadap bobot dan panjang organ pencernaan. Penelitian dilaksanakan pada tanggal 11 Agustus-11 Oktober 2014 di Fakultas Peternakan dan Pertanian, Universitas Diponegoro. Materi yang digunakan adalah Day Old Chick (DOC) ayam kampung sebanyak 100 ekor (unsexed) dengan bobot badan 37,90 \pm 1,36 g. Rancangan percobaan yang digunakan adalah Rancangan Acak Lengkap (RAL). Perlakuan dosis kultur kering probiotik Rhizopus oryzae T0 (kontrol), T1 $(0,1 \%)$ dan T2 $(0,2 \%)$. Hasil penelitian menunjukkan bahwa pemberian probiotik Rhizopus oryzae dalam ransum berpengaruh nyata $(\mathrm{P}<0,05)$ terhadap sebagian besar bobot dan panjang organ pencernaan ayam kampung. Bobot organ pencernaan tertinggi pada perlakuan T1 yang kemudian diikuti T2 dan T0, sedangkan panjang organ pencernaan diperoleh tertinggi pada
\end{abstract}


perlakuan $\mathrm{T} 2$ yang kemudian diikuti $\mathrm{T} 1$ dan $\mathrm{T} 0$. Kesimpulan penelitian adalah pemberian Rhizopus oryzae dengan dosis $0,1 \%$ dan $0,2 \%$ pada pakan ayam kampung dapat meningkatkan sebagian besar bobot dan panjang organ pencernaan ayam kampung.

Kata kunci: Probiotik, fungi, organ pencernaan, ayam kampung

\section{PENDAHULUAN}

Ayam kampung atau ayam buras sudah banyak dikenal masyarakat dan banyak dibudidayakan di pedesaan, karena perawatannya tergolong mudah, daya tahan tubuhnya cukup tinggi, mudah beradaptasi dan harganya relatif lebih mahal dari ayam broiler. Ayam jenis ini banyak digemari masyarakat karena baik daging maupun telurnya memiliki cita rasa yang lebih disukai dibandingkan ayam broiler (Aswanto, 2010). Pemeliharaan ayam kampung pada umumnya dilakukan secara "umbaran" di halaman dan di kebun sekitar rumah. Sebagian kecil masyarakat mengusahakannya secara semi intensif dan intensif (Yuwanta, 2004).

Usaha untuk meningkatkan produktivitas dan mengurangi angka kematian pada ayam kampung yang dipelihara secara intensif salah satunya dengan pemberian aditif pakan. Pemberian aditif pakan probiotik dilakukan dengan maksud untuk menjaga keseimbangan ekosistem di dalam usus, memperbaiki struktur dinding sel organ pencernaan, peningkatan ketahanan terhadap bakteri patogen dan memperbaiki sistem imunitas ayam (Sarwono et al., 2012).

Probiotik didefinisikan sebagai makanan tambahan berupa mikroba hidup baik bakteri maupun kapang yang mempunyai pengaruh menguntungkan pada hewan inang dengan memperbaiki mikroba dalam organ pencernaan McDonald et al. (2002). Probiotik yang terdapat dalam organ pencernan ayam kampung juga dapat menetralisir toksin yang dihasilkan bakteri patogen, menghambat pertumbuhan bakteri patogen dengan mencegah kolonisasinya di dinding usus halus, mempengaruhi aktivitas enzim di usus halus, asimilasi kolesterol dan meningkatkan pertumbuhan serta performan ayam kampung (Abun, 2008). Probiotik yang banyak digunakan saat ini termasuk dalam kelompok bakteri asam laktat. Selain itu probiotik dapat juga berasal dari spesies fungi atau khamir (Sugiharto, 2014).

Fungi merupakan mikroorganisme yang mempunyai tingkat resisten yang tinggi dan dapat hidup pada kondisi yang kurang menguntungkan serta mudah dikembang biakkan (Sudarmono, 2013). Salah satu spesies yang dapat dijadikan probiotik adalah Rhizopus oryzae yang merupakan golongan fungi filamentus (Yudiarti et al., 2012).

Tujuan penelitian adalah untuk mengetahui pengaruh pemberian probiotik Rhizopus oryzae sebagai aditif pakan pada ayam kampung terhadap bobot dan panjang organ pencernaan. Manfaat yang diharapkan dari penelitian ini adalah memberikan informasi tentang probiotik Rhizopus oryzae sebagai aditif pakan pada ransum ayam kampung terhadap bobot dan panjang organ pencernaan ayam kampung. Hipotesis penelitian ini adalah penambahan probiotik Rhizopus oryzae dalam ransum ayam kampung dapat meningkatkan laju pertumbuhan bobot dan panjang organ pencernaan ayam kampung. 


\section{MATERI DAN METODE}

\section{Materi}

Penelitian dilaksanakan pada tanggal 11 Agustus-11 Oktober 2014 di Fakultas Peternakan dan Pertanian, Universitas Diponegoro. Materi yang digunakan dalam penelitian ini Day Old Chick (DOC) ayam kampung dari PT. Tirto Hartono, Sleman, Yogyakarta sebanyak 100 ekor dengan

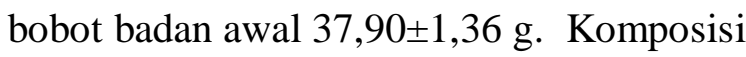
ransum dapat dilihat pada Tabel 1 .

Kandang yang digunakan adalah kandang battery, tempat pakan, tempat minum, plastik, timbangan digital, cent to gram, cawan petri, oven, autoklaf, erlenmeyer, pipet, tabung reaksi, kentang, agar dan dextrose.

\section{Metode}

Penelitian dibagi menjadi 3 tahap yaitu persiapan, pelaksanaan dan pengambilan data. Persiapan dilakukan mulai dari pembiakan $R$. oryzae pada media PDA, kemudian diinkubasikan pada suhu $37^{\circ} \mathrm{C}$ selama 48 jam. Selanjutnya pembuatan sediaan kultur kering probiotik dengan cara $R$. oryzae yang sudah diinkubasi diambil 5 biakan kemudian dicampurkan secara merata ke dalam $1 \mathrm{~kg}$ dedak dan 5 biakan lainnya ke dalam $1 \mathrm{~kg}$ jagung giling masing-masing ditambah aquades secukupnya, kemudian ditutup rapat dan diperam selama 1 minggu. Setiap 2 hari sekali dilakukan pengadukan agar biakan merata disemua pakan baterai, setelah 1 minggu dedak dan jagung dikeringkan. Persiapan lainnya meliputi pengadaan bahan pakan, persiapan kandang, sanitasi kandang, penyiapan brooder, penyekatan kandang sesuai jumlah perlakuan, persiapan perlengkapan pemeliharaan dan pembelian DOC ayam kampung. Tiap petak kandang diberi penerangan bohlam 25 watt.

Tabel 1. Komposisi dan Kandungan Nutrien Ransum

\begin{tabular}{|c|c|}
\hline Bahan Pakan & Persentase \\
\hline & ----------- \% --------- \\
\hline Jagung giling & 35 \\
\hline Bekatul & 46 \\
\hline Tepung ikan & 18 \\
\hline Tepung cangkang kerang & 1 \\
\hline Jumlah & 100 \\
\hline EM (kkal/kg) & 3215,32 \\
\hline Kadar air $(\%)$ & 10,01 \\
\hline Protein $(\%)$ & 15,76 \\
\hline Lemak $(\%)$ & 14,91 \\
\hline Serat kasar (\%) & 5,27 \\
\hline $\mathrm{Abu}(\%)$ & 13,08 \\
\hline Kalsium (\%) & 2,00 \\
\hline Phosphor (\%) & 1,32 \\
\hline
\end{tabular}

Sumber: PT. Charoen Pokphand Tbk, Makasar, 2014.

Tahap pelaksanaan dimulai dari chick kandang baterai, 6 ekor ayam dan in, setiap petak kandang terdiri dari 3 dilengkapi dengan 1 buah tempat makan 
dan minum. Ransum perlakuan diberikan sejak awal dengan tambahan probiotik yaitu (T0) $0 \%$, (T1) 0,1\% dan (T2) 0,2\%. Setiap 1 gram kultur kering probiotik yang ditambahkan dalam ransum terkandung koloni fungi $R$. oryzae sebanyak 5,2 × $10^{6}$ $c f u / g$. Ransum diberikan pada ayam setiap hari sedangkan air minum diberikan secara ad libitum. Sisa ransum ditimbang seminggu sekali.

Tahap pengambilan data dilaksanakan saat ayam kampung berumur 2 bulan. Sampel ayam yang diambil sebanyak 15 ekor, masing-masing 1 ekor untuk tiap perlakuan dan ulangan. Sampel ayam disembelih kemudian dibelah bagian abdomen dan diambil organ pencernaannya. Penimbangan bobot organ pencernaan dimulai dari esophagus sampai kloaka dengan menggunakan timbangan analitis dan pengukuran panjang organ pencernaan dimulai dari esophagus sampai kloaka dengan menggunakan penggaris.

\section{Rancangan Penelitian}

Penelitian menggunakan rancangan acak lengkap (RAL) dengan 3 perlakuan dan 5 ulangan. Setiap unit ulangan penelitian terdiri dari 5 ekor ayam. Perlakuan penelitian terdiri dari :

$\mathrm{T} 0$ = Ransum tanpa probiotik Rhizopus oryzae (kontrol)

$\mathrm{T} 1=$ Ransum $+0,1 \%$ probiotik Rhizopus oryzae

$\mathrm{T} 2=$ Ransum $+0,2 \%$ probiotik Rhizopus oryzae

Data hasil penelitian diolah secara statistik menggunakan analisis ragam, apabila ada pengaruh nyata dilanjutkan uji wilayah ganda Duncan pada taraf 5\% (Steel and Torrie, 1995).

\section{HASIL DAN PEMBAHASAN}

\section{Bobot Organ Pencernaan}

Bobot organ pencernaan ayam kampung pada masing-masing perlakuan dapat dilihat pada Tabel 2. Hasil analisis ragam menunjukkan bahwa perlakuan pemberian $R$. oryzae berpengaruh nyata $(\mathrm{P}<0,05)$ terhadap sebagian besar bobot organ pencernaan ayam kampung

Tabel 2. Rataan Bobot Organ Pencernaan Ayam Kampung pada Berbagai Dosis Pemberian probiotik Rhizopus oryzae

\begin{tabular}{lccc}
\hline \multirow{2}{*}{ Parameter } & \multicolumn{3}{c}{ Perlakuan } \\
\cline { 2 - 4 } & T0 & T1 & T2 \\
\hline & $---------------g--------------$ & $1,07^{\mathrm{b}}$ \\
Esophagus & $0,99^{\mathrm{c}}$ & $1,14^{\mathrm{a}}$ & $4,70^{\mathrm{a}}$ \\
Tembolok (Crop) & $3,94^{\mathrm{b}}$ & $4,71^{\mathrm{a}}$ & 3,48 \\
Proventrikulus & 3,08 & 3,47 & 28,08 \\
Ventrikulus (Gizzard) & 23,67 & 27,54 & $28,60^{\mathrm{a}}$ \\
Usus Halus & $23,40^{\mathrm{c}}$ & $25,60^{\mathrm{b}}$ & $3,20^{\mathrm{a}}$ \\
Sekum & $2,50^{\mathrm{b}}$ & $3,22^{\mathrm{a}}$ & $1,30^{\mathrm{a}}$ \\
Usus Besar & $1,06^{\mathrm{b}}$ & $1,26^{\mathrm{a}}$ & 2,84 \\
Kloaka & 2,20 & 2,64 & 11,93 \\
Hati & 10,84 & 11,96 & \\
\hline
\end{tabular}

${ }^{\text {a,b,c }}$ Superskrip yang berbeda pada baris yang sama menunjukkan perbedaan yang nyata $(\mathrm{P}<0,05)$. 
Hasil analisis statistik menunjukkan ada pengaruh pemberian aditif pakan probiotik $R$. oryzae terhadap bobot esophagus, tembolok, usus halus, sekum dan usus besar ayam kampung.

Bobot esophagus tertinggi diperoleh pada perlakuan T1 (Tabel 2) yang kemudian diikuti T2, T0. Hal ini menunjukkan bahwa tambahan probiotik pada pakan mampu meningkatkan bobot esophagus. Peningkatan bobot esophagus ini kemungkinan disebabkan tambahan probiotik mampu meningkatan kecernaan pakan di usus. Sesuai dengan pendapat Kompiang (2009) bahwa probiotik dapat meningkatkan kecernaan dan penyerapan nutrien pakan. Adapun mekanisme kerja probiotik sebagai berikut, probiotik membantu mencerna pakan dengan cara mensekresikan enzim pencernaan sehingga pakan yang tercerna dan diserap menjadi lebih banyak dibandingkan dengan pakan yang tanpa tambahan probiotik. Akibatnya yaitu ketersediaan energi metabolis menjadi lebih banyak juga. Hal ini menyebabkan energi untuk pertumbuhan menjadi tinggi termasuk pertumbuhan organ pencernaan lainnya seperti esophagus.

Bobot tembolok tertinggi diperoleh pada perlakuan T1 (Tabel 2) yang kemudian diikuti T2, T0. Hal ini menunjukkan bahwa tambahan probiotik pada pakan mampu meningkatkan bobot tembolok. Peningkatan bobot tembolok ini kemungkinan disebabkan tambahan probiotik mampu memperlambat laju pencernaan, sehingga nutrien yang dicerna dan diserap oleh ternak semakin banyak. Hal ini sesuai dengan pendapat Mangisah et al., (2009) bahwa penambahan probiotik menyebabkan laju digesta menjadi lambat sehingga semakin banyak nutrien yang dapat dicerna dan diserap ternak. Adapun mekanisme kerja probiotik sebagai berikut, probiotik mampu memperlambat laju digesta karena aktivitas enzim dalam proses penguraian zat pakan menjadi komponen yang lebih sederhana agar mudah dicerna dan diserap oleh ternak sehingga pakan yang dicerna dan diserap akan lebih banyak serta meningkatnta ketersediaan nutrien untuk sintesis organ pencernaan lainnya termasuk tembolok. Wahju menambahkan bahwa cepatnya laju digesta melewati saluran pencernaan dapat menurunkan daya cerna, akibatnya penurunan ketersedian energi dan ayam mengkonsumsi ransum lebih banyak sampai kebutuhan energi tercukupi.

Bobot usus halus tertinggi diperoleh pada perlakuan T2 (Tabel 2) yang kemudian diikuti T1, T0. Hal ini menunjukkan bahwa tambahan probiotik pada pakan mampu meningkatkan bobot usus halus. Peningkatan bobot usus halus ini kemungkinan disebabkan tambahan probiotik mampu membantu proses pencernaan karena probiotik Rhizopuz oryzae dapat menghasilkan enzim protease. Sesuai dengan pendapat Yudiarti et al., (2012) bahwa fungi dapat menghasilkan enzim protease. Adapun mekanisme kerjanya sebagai berikut, probiotik membantu proses pencernaan dengan cara menghasilkan enzim pencernaan seperti enzim protease yang dapat membantu menguraikan protein menjadi asam amino sehingga protein yang dicerna semakin banyak dan pemanfaatan energi dapat diserap tubuh dengan maksimal dibandingkan usus halus yang tanpa tambahan probiotik. Semakin banyak pakan yang dicerna dan diserap akan meningkatkan kinerja usus sehingga usus mengalami perluasan permukaan. Menurut Sugito (2007) bahwa banyaknya pakan yang diabsorpsi menyebabkan vili usus semakin berkembang untuk memperluas 
permukaan usus, sehingga tumbuhnya vili berakibat semakin tinggi bobot dan ukuran usus halus.

Bobot sekum tertinggi diperoleh pada perlakuan T1 (Tabel 2) yang kemudian diikuti T2, T0. Hal ini menunjukkan bahwa tambahan probiotik pada pakan mampu meningkatkan bobot sekum. Peningkatan bobot sekum ini kemungkinan disebabkan tambahan probiotik mampu membantu proses pencernaan karena probiotik Rhizopuz oryzae dapat menghasilkan enzim lignolitik yang digunakan untuk mengurai serat kasar. Sesuai dengan pendapat Dewi et al., (2005) bahwa Rhizopus oryzae memiliki enzim amilase, selulase, dan xylanase yang merupakan enzim pendegradasi karbohidrat dan hasil degradasi karbohidrat berupa senyawa yang lebih sederhana. Adapun mekanisme kerjanya sebagai berikut, probiotik membantu proses pencernaan dengan menghasilkan enzim pencernaan seperti enzim lignolitik yang menyebabkan digesta serat kasar di sekum lebih mudah dicerna karena dibantu dengan enzim lignolitik dari probiotik dan enzim dari inangnya sehingga pakan yang tercerna menjadi lebih banyak serta penyerapan nutrien lebih banyak juga dibandingkan sekum yang tanpa tambahan probiotik.

Bobot usus besar tertinggi diperoleh pada perlakuan T2 (Tabel 2) yang kemudian diikuti T1, T0. Hal ini menunjukkan bahwa tambahan probiotik pada pakan mampu meningkatkan bobot usus besar. Peningkatan bobot usus besar ini kemungkinan disebabkan tambahan probiotik mampu meningkatkan kecernaan dan penyerapan nutrien pakan. Sesuai dengan pendapat Widyastuti dan Soarianawati (1999) bahwa probiotik mampu menghambat pertumbuhan patogen serta meningkatkan kecernaan dan penyerapan nutrien pakan. Adapun mekanisme kerja probiotik sebagai berikut, probiotik membantu menghambat pertumbuhan patogen dengan cara kompetisi antara bakteri patogen dan non patogen yang untuk mendapatkan tempat tinggal dan nutrien. Bakteri patogen menghasilkan toksin untuk patogen sehingga patogen keluar bersama feses. Pakan yang tadinya tercerna hanya sedikit, dengan adanya tambahan probiotik pakan yang tercerna dan diserap menjadi lebih banyak dan energi yang digunakan untuk pertumbuhan organ pencernaan lainnya menjadi lebih tinggi seperti usus besar.

\section{Panjang Organ Pencernaan}

Panjang organ pencernaan ayam kampung pada masing-masing perlakuan dapat dilihat pada Tabel 3.

Tabel 3. Rataan Panjang Organ Pencernaan Ayam Kampung pada Berbagai Dosis Pemberian probiotik Rhizopus oryzae

\begin{tabular}{lccc}
\hline \multirow{2}{*}{ Parameter } & \multicolumn{3}{c}{ Perlakuan } \\
\cline { 2 - 4 } & \multicolumn{1}{c}{ T0 } & \multicolumn{1}{c}{ T1 } & \multicolumn{1}{c}{ T2 } \\
\hline Esophagus & $2,84^{\mathrm{b}}$ & $3,60^{\mathrm{a}}$ & $3,64^{\mathrm{a}}$ \\
Tembolok & $2,93^{\mathrm{b}}$ & $3,23^{\mathrm{a}}$ & $3,22^{\mathrm{a}}$ \\
(Crop) & 4,72 & 5,21 & 5,02 \\
Proventrikulus & $4,-1$ & 4,28 \\
Ventrikulus & 3,57 & 4,29 & \\
(Gizzard) & $98,60^{\mathrm{b}}$ & $110,58^{\mathrm{a}}$ & $110,08^{\mathrm{a}}$ \\
Usus Halus & $9,24^{\mathrm{c}}$ & $9,56^{\mathrm{b}}$ & $9,74^{\mathrm{a}}$ \\
Sekum & $3,96^{\mathrm{b}}$ & $4,73^{\mathrm{a}}$ & $4,82^{\mathrm{a}}$ \\
Usus Besar & 2,69 & 3,28 & 3,25 \\
Kloaka & 4,52 & 4,54 & 4,90 \\
Hati &
\end{tabular}

a,b,c Superskrip yang berbeda pada baris yang sama menunjukkan perbedaan yang nyata $(\mathrm{P}<0,05)$.

Hasil analisis ragam menunjukkan bahwa perlakuan pemberian $R$. oryzae berpengaruh nyata $(\mathrm{P}<0,05)$ terhadap 
sebagian besar panjang organ pencernaan ayam kampung

Hasil analisis statistik menunjukkan ada pengaruh pemberian aditif pakan probiotik Rhizopus oryzae terhadap panjang esophagus, tembolok, usus halus, sekum dan usus besar ayam kampung.

Panjang esophagus tertinggi diperoleh pada perlakuan T2 (Tabel 3) yang kemudian diikuti T1, T0. Hal ini menunjukkan bahwa tambahan probiotik pada pakan mampu meningkatkan panjang esophagus. Peningkatan panjang esophagus ini kemungkinan disebabkan tambahan probiotik mampu membantu proses pencernaan dengan cara menghambat pertumbuhan bakteri patogen. Sesuai dengan pendapat Hassan (2006) bahwa penambahan probiotik mampu mempertahankan mikroba bermanfaat dalam organ pencernaan dan sebaliknya menghambat pertumbuhan bakteri patogen. Adapun mekanisme kerja probiotik sebagai berikut, probiotik mampu menghambat bakteri patogen dengan cara probiotik menempel pada mukosa usus untuk membentuk suatu lapisan yang dapat menghalangi perlekatan dan kolonisasi bakteri patogen pada mukosa usus sehingga memberikan keuntungan bagi inang dengan pakan yang masuk dapat dicerna secara optimal dan nutrien yang diserap dapat dimanfaatkan untuk pertumbuhan organ pencernaan yang lainnya seperti esophagus.

Panjang tembolok tertinggi diperoleh pada perlakuan T1 (Tabel 3) yang kemudian diikuti T2, T0. Hal ini menunjukkan bahwa tambahan probiotik pada pakan mampu meningkatkan panjang tembolok. Peningkatan panjang tembolok ini kemungkinan disebabkan tambahan probiotik mampu memproduksi toksin untuk menghambat pertumbuhan bakteri patogen sehingga dapat menjaga keseimbangan mikroflora usus. Sesuai dengan pendapat Huyghebaert et al., (2011) bahwa pemberian probiotik pada ternak dimaksudkan untuk menjaga keseimbangan ekosistem di dalam usus dan peningkatan ketahanan terhadap bakteri patogen. Adapun mekanisme kerja probiotik sebagai berikut, probiotik membantu proses pencernaan dengan cara persaingan antara bakteri patogen dan non patogen yang menempel pada mukosa usus. Bakteri non patogen menghasilkan toksin untuk menghambat pertumbuhan bakteri patogen keluar bersama feses dan di saat bakteri non patogen dan patogen di organ pencernaan dalam keadaan seimbang maka ternak mampu menggunakan pakan dengan efisien sehingga pakan yang masuk dapat tercerna dan diserap lebih banyak serta penggunaan energi untuk pertumbuhan menjadi lebih tinggi, yang mengakibatkan pertumbuhan organ pencernaan lainnya seperti ukuran atau panjang meningkat seperti tembolok.

Panjang usus halus tertinggi diperoleh pada perlakuan T1 (Tabel 3) yang kemudian diikuti T2, T0. Hal ini menunjukkan bahwa tambahan probiotik pada pakan mampu meningkatkan panjang usus halus. Peningkatan panjang usus halus ini kemungkinan disebabkan tambahan probiotik membantu proses pencernaan dengan menghasilkan enzim ekstraseluler untuk meningkatkan kecernaan dan penyerapan nutrien. Sesuai dengan pendapat Melviyanti et al., (2013) bahwa probiotik dapat menghasilkan enzim proteolitik (pengurai protein) maupun lignolitik (pengurai serat kasar). Adapun mekanisme kerja probiotik sebagai berikut, probiotik membantu menghasilkan enzimenzim kecernaan baik untuk mencerna lemak (lipase), protein (protease), maupun karbohidrat (amilase) yang membantu proses pencernaan senyawa komplek 
menjadi lebih sederhana. Semakin banyak pakan yang masuk, maka semakin tinggi kinerja enzim untuk menghidrolisis pakan menjadi lebih sederhana sehingga pakan yang tercerna dan terserap lebih banyak. Akibatnya kinerja usus halus semakin meningkat yang menyebabkan usus halus mengalami perluasan sehingga menjadi lebih panjang dibandingankan pakan yang tanpa pemberian tambahan probiotik.

Panjang sekum tertinggi diperoleh pada perlakuan T1 (Tabel 3) yang kemudian diikuti T2, T0. Hal ini menunjukkan bahwa tambahan probiotik pada pakan mampu meningkatkan panjang sekum. Peningkatan panjang sekum ini kemungkinan disebabkan tambahan probiotik mampu menjaga keseimbangan mikroba usus. Sesuai dengan pendapat Sudarmono (2013) bahwa pemberian probiotik juga dapat menjaga keseimbangan komposisi mikroba dalam organ pencernaan, sehingga berakibat pada peningkatkan daya cerna pakan. Adapun cara mekanisme kerja probiotik sebagai berikut, probiotik membantu menjaga keseimbangan mikroba usus dengan cara competitive exclution antara bakteri patogen dan non patogen. Bakteri patogen menghasilkan toksin untuk menekan mikroba patogen keluar bersama feses sehingga pakan yang diberikan akan lebih efisien karena nutrisi yang tadinya dicerna hanya sedikit, dengan adanya probiotik pakan dapat dicerna dan diserap akan lebih banyak serta energi yang digunakan untuk pertumbuhan juga akan lebih tinggi. Semakin banyak pakan yang dicerna mengakibatkan kinerja sekum akan lebih tinggi yang mengakibatkan sekum mengalami perluasan permukaan menjadi lebih panjang. Akhadiarto (2010) menambahkan bahwa banyaknya mikroba yang menguntungkan di dalam sekum mengakibatkan peningkatan pencernaan dan penyerapan zat-zat nutrisi yang terkandung di dalam pakan lebih efisien.

Panjang usus besar tertinggi diperoleh pada perlakuan T2 (Tabel 3) yang kemudian diikuti T1, T0. Hal ini menunjukkan bahwa tambahan probiotik pada pakan mampu meningkatkan panjang usus besar. Peningkatan panjang usus besar ini kemungkinan disebabkan tambahan probiotik mampu menambah jumlah populasi mikroba yang menguntungkan. Sesuai dengan pendapat Safingi et al. (2013) bahwa penggunaan probiotik dalam ransum dapat menambah jumlah populasi mikroba yang menguntungkan bagi ternak, mencegah berkembangnya mikroba yang merugikan dalam organ pencernaan sehingga dapat meningkatkan pencernaan pakan, dengan demikian pemberian probiotik dapat mengefisienkan konsumsi pakan. Adapun mekanisme kerja probiotik sebagai berikut, probiotik membantu menambah jumlah populasi mikroba menguntungkan dengan cara probiotik melekatkan diri di mukosa usus dan menghasilkan toksin untuk menghalangi pertumbuhan mikroba merugikan sehingga pakan yang tadinya dicerna hanya sedikit, dengan adanya probiotik pakan yang dicerna dan diserap akan lebih banyak dan kinerja usus juga menjadi lebih tinggi karna banyaknya pakan yang masuk untuk dicerna oleh enzim pencernaan, yang mengakibatkan usus mengalami perluasan permukaan menjadi lebih panjang.

\section{KESIMPULAN DAN SARAN}

\section{Kesimpulan}

Berdasarkan hasil penelitian, simpulan yang dapat diambil adalah pemberian probiotik Rhizopus oryzae 
dengan dosis $0,1 \%$ dan $0,2 \%$ dalam ransum ayam kampung dapat meningkatkan sebagian besar bobot dan panjang organ pencernaan ayam kampung.

\section{Saran}

Perlu penelitian lebih kanjut mengenai penggunaan probiotik Rhizopus oryzae pada dosis yang lain, ayam broiler dan perubahan fisiologi yang lainnya.

\section{DAFTAR PUSTAKA}

Abun. 2008. Hubungan Mikroflora dengan Metabolisme dalam Organ Pencernaan Unggas dan Monogastrik. Makalah Ilmiah Nutrisi Dan Makanan Ternak Fakultas Peternakan Universitas Padjadjaran Jatinangor, Bandung

Akhadiarto, S. 2010. Pengaruh pemberian probiotik temban biovet dan biolacta terhadap persentase karkas, bobot lemak abdomen dan organ dalam ayam broiler. Jurnal Sains dan Teknologi, 12 (1) : 53-59.

Aswanto. 2010. Beternak Ayam Kampung. Balai Pengkajian Teknologi Pertanian, Kalimantan Barat.

Dewi, C., T. Purwoko, dan A. Pangastuti. 2005. Produksi gula reduksi oleh Rhizopus oryzae dari substrat bekatul. Jurusn Biologi Fakultas MIPA Universitas Negeri Sebelas Maret, Surakarta. J. Bioteknologi, 2 (1) : 21-26. ISSN 0216-6887.

Hassan, Z. H. 2006. Isolasi Lactobacillus, bakteri asam laktat dari feses dan organ organ pencernaan ayam. Makalah Seminar Nasional Teknologi Peternakan dan Veteriner, Kalimantan Selatan.

Huyghebaert, G., R. Ducatelle and F. Van Immerseel, 2011. An update on alternatives to antimicrobial growth promoters for broilers. J. Vet. 187 : $182-188$.

Kompiang, I P. 2009. Pemanfaatan mikroorganisme sebagai probiotik untuk meningkatkan produksi ternak unggas di Indonesia. Pengembangan Inovasi Pertanian, 2 (3) : 177 - 191.

Mangisah I, N. Suthama dan H. I. Wahyuni. 2009. Pengaruh Penambahan Starbio dalam ransum berserat kasar tinggi terhadap performa itik. Makalah Seminar Nasional Kebangkitan Peternakan Universitas Diponegoro, Semarang.

McDonald, P., A.R. Edwards, J.F.D. Greenhalgh and C. A. Morgan. 2002. Animal nutrition. $6^{\text {th }}$ Ed., Ashford Colour Press Ltd., Gosport, British.

Melviyanti, M. T., N. Iriyanti dan Roesdiyanto. 2013. Penggunaan pakan fungsional mengandung omega 3, probiotik dan isolat antihistamin $\mathrm{N}_{3}$ terhadap bobot dan indeks telur ayam kampung. Jurnal Ilmiah Peternakan, 1 (2) : 677 683.

Nugroho, A. P., I. Murni W., E. Reftiana Z. dan A. S. Harti. 2013. Tempe bekatul kitosan sebagai biosuplemen prebiotik sehat alami bagi ibu hamil. Prosiding SNST ke-4. p 10-14.

Safingi, A., M. Mufti dan N. Iriyanti. 2013. Penggunaan berbagai jenis probiotik dalam ransum ayam arab terhadap konsumsi pakan dan income over feed cost. Jurnal Ilmiah Peternakan, $1(3): 970$ - 975 .

Sarwono, S.R., T. Yudiarti dan E. Suprijatna. 2012. Pengaruh pemberian probiotik terhadap trigliserida darah, lemak abdominal, bobot dan panjang organ pencernaan ayam kampung. J. Anim Agric. 1 (2) : $157-167$.

Sudarmono. 2013. Sukses Meramu Probiotik untuk Perikanan, 
Peternakan dan Pertanian. Pustaka Baru Press, Yogyakarta.

Sugiharto, S. 2014. Role of nutraceuticals in gut health and growth performance of poultry. J. Saudi Soc. Agric. Sci. $p 1$ - 13. (http://dx.doi.org/10.1016/j.jssas.20 14.06.001).

Sugito, W. M., D. A. Astuti, E. Handharyani dan Chairul. 2007. Morfometrik usus dan performa ayam broiler yang diberi cekaman panas dan ekstrak n-heksana kulit batang jaloh (Salix tereasperma Roxb). J. Poult Sci. 30 (3) : 198206. ISSN 0126-0472.

Widyastuti, Y. dan E. Soarianawati. 1999. Karakter bakteri asam laktat Enterococcus sp. yang diisolasi dari organ pencernaan ternak. $J$. mikrobiologi Indonesia. 4 (2): 5053.

Yudiarti, T., V. D.Yunianto B.I, R. Murwani dan E. Kusdiyantini. 2012. The effect of Chrysonilia crassa additive on duodenal \& caecal morphology, bacterial and fungal number, and productivity of ayam kampung. Int. J. Sci. and Eng., 3 (2) : $26-29$.

Wahju, J. 1992. Ilmu Nutrisi Unggas. Gadjah Mada University Press, Yogyakarta.

Yuwanta, T. 2004. Dasar Ternak Unggas. Kanisius, Yogyakarta. 